\title{
DNA Technologies in Criminal Investigation and Courts
}

\begin{abstract}
DNA profiling has been assuming a prominent role in the activities of the criminal justice system. Genetic technologies support criminal investigations, while also being seen as holding a highly valuable potential for producing evidence to be used in courts. This chapter has two main objectives: on the one hand, to describe and explain the ways that DNA technologies can be used in criminal investigation and turned into DNA evidence in criminal proceedings; on the other hand, this chapter aims to systematize the main lines of academic literature within the social sciences which have been developed to study the social implications and transformations of cultures and professional practices arising from the presence of DNA technology in the criminal justice system. Besides, the chapter also pays particular attention to the social nature of the high expectations associated to the "infallibility" of DNA technologies and how the media portrays the use of forensic genetics and further exacerbates such notions.
\end{abstract}

Keywords Chain of custody $\bullet$ Criminal investigation $\bullet$ Courts $\bullet$ Infallibility myth $\bullet$ CSI effect 


\section{DNA Technologies and Its Application in Criminal INVESTIGATION}

There is now a broad consensus that DNA technologies play a vital role in justice systems in various regions of the world (Hindmarsh \& Prainsack, 2010; Kruse, 2016; Lawless, 2016; Lynch, Cole, McNally, \& Jordan, 2008; Toom, 2018; Williams \& Johnson, 2008). DNA technologies support the collection of information that helps the criminal investigation, and DNA evidence is considered to have great value for judicial procedures.

However, the aura of infallibility associated with DNA technologies generates expectations which are often exaggerated and dissociated from the concrete reality of criminal investigation. It is therefore essential to recognize and identify the potential risks arising from the use of DNA technology, in order to prevent possible errors and threats to civil rightsincluding upholding the presumption of innocence, genetic privacy and the moral and physical integrity of suspects or persons accused of crimes (McCartney, 2006; Murphy, 2007; Nuffield Council on Bioethics, 2007).

Identification of individuals using DNA profiles is often described as the most important discovery in the world of forensic science since the fingerprint (Lynch et al., 2008) and has even been designated by several authors as the most significant mean of human identification of the modern era. Development of studies on the use of DNA for individual identification depends upon broad zones that exist between the genes that are generally called "non-coding DNA". These intergenic zones reveal specific chemical sequences that are supposed to be unique to each individual and therefore produce a "genetic fingerprint". Comparison of different "genetic fingerprints" enables us to observe whether different samples of DNA come from the same individual or different individuals. There is also a biological relationship of descendance between the suppliers of different samples that might be compared. In short, each person's DNA is unique, except in the case of identical twins.

A new epistemology of forensic identification (Cole, 2009) claims that it is impossible to achieve "perfect" individualization, and therefore, we should speak about probabilities rather than certainties (Kaye, 2009; Saks \& Koehler, 2008). Scientific authorities generally argue that absolute individualization is a theoretical goal, but even excluding identical twins, the inclusion of more markers in a DNA profile analysis leads to an increased likelihood of observation of somatic mutations, that is, intra-individual heterogeneity (Amorim, 2002). 
Forensic DNA analysis usually involves comparisons between genetic profiles extracted from biological samples collected from a specific site, object or person which is thought to be associated to a crime, in order to determine the likelihood that such samples come from a particular person (e.g., from a suspect, or victim, of a specific crime). Biological substances collected at crime scenes - such as blood, hair, semen, urine, skin, saliva, sweat and tears-all contain DNA. A DNA sample can also be obtained through a mouth smear from an identified person, or by collecting hair samples (including hair roots, since they contain the cells needed for analysis), blood samples (usually achieved nowadays by pricking the finger) or by scraping part of the body to remove a small sample of a person's skin.

A molecular biological technique, called polymerase chain reaction (PCR) is fundamental for analysing DNA polymorphisms. This technique makes it possible to replicate in vitro and amplify and analyse trace amounts of DNA. Nowadays, this technique is frequently used in the preparation of DNA profiles for criminal identification and makes it possible to pair suspects with blood, hair, saliva or sperm samples. DNA profiles are also often used for forensic civilian identification purposes, in particular for paternity testing and identification of missing persons and human remains (Bier, 2018; Smith, 2017; Toom, 2017).

A technical problem raised by DNA profiles is the fact that contamination with DNA from an outside source can occur, both at the time of collection and in the scientific laboratory. Contamination of the DNA sample is frequent in crime scenes, in old and degraded samples, in corpses and human remains. False identifications are likely to happen when used in partial profiles due to insufficient quantity or degradation of DNA (Murphy, 2007).

In addition to the aforementioned risks, there are ethical issues that derive from the type of information that can be obtained from DNA analysis. While traditional fingerprints only reveal a person's identity, samples used for DNA profiles may reveal much more information, namely about the individual's kinship ties, which may be unknown to the individual (Haimes, 2006; Kim, Mammo, Siegel, \& Katsanis, 2011). With advances in the knowledge of the human genome, even the so-called non-coding DNA may in the future be associated with sensitive information, such as diseases and behavioural traits (Duster, 2003; Williams \& Johnson, 2004a).

The myth of the infallibility of genetic identification can condition the conduct of the police investigation itself and the assessment of evidence in court. Hence, it is desirable to question the reliability and scope of the 
DNA evidence and the consideration of the circumstances associated with each case. It is, therefore, necessary to guarantee the principle of taking precautions when using DNA profiling as a means of evidence, since in certain circumstances it may become controversial and maybe a source of abuse and judicial errors (Gill, 2014, 2016; Schiffer \& Champod, 2008).

\section{From the Crime Scene to the Laboratory AND THE COURT}

The presence of DNA technology in the criminal justice system involves multiple professionals and differentiated spaces. Within the framework of the so-called chain of custody, the focus is on the crime scene and its observation to identify and collect biological traces that may subsequently be useful for identifying a perpetrator. Subsequently, the biological traces are analysed in a laboratory context. Finally, scientific reports on the DNA analysis are presented to the persons responsible for judging the case in court.

Social science studies have revealed that, in an initial stage, various controversies arose, associated to doubts about the credibility and robustness of DNA technology that accompanied the start of its practical applications in human identification (Aronson, 2007; Jasanoff, 1995; Lynch \& Jasanoff, 1998). However, DNA testing gained a more respected status due to its unparalleled capacity to identify criminal suspects (Lynch et al., 2008; Williams \& Johnson, 2008). As Michael Lynch argues, DNA testing is treated "as both the source and object of an extraordinary and even absolute, degree of certainty in criminal law" (Lynch, 2013, p. 60).

Claims for the operational utility and scientific standing of forensic DNA profiling are often made in the context of new concepts and methods designed to improve the quality and effectiveness of police criminal investigation practices (Williams \& Johnson, 2008). Therefore, forensic DNA evidence is often viewed as capable of enhancing police practices with some degree of "objectivity" associated with the scientific authority of DNA technologies (Cole \& Lynch, 2006; Costa, 2017; Santos, 2014). However, studies with police forces reveal that police professionals consider that DNA testing is subject to various contingencies, which is why it should be seen primarily as a source of intelligence, to be taken into account in criminal investigation in conjunction with other types of leads and evidence (Huey, 2010; Machado \& Granja, 2019). 
In short, as the anthropologist Corinna Kruse (2016) points out in her study about the Swedish justice system, the views and uses of DNA evidence tend to vary. The different professionals who are involved in investigating crimes and taking decisions on whether suspects should be accused or exonerated, construct different meanings and interpretations regarding the value of forensic genetics. The author illustrates the multiplicity of meanings attributed to DNA testing by different professionals, as follows:

To a crime scene technician, forensic evidence is something that can be produced by traces $(\ldots)$ from a crime scene. To a police investigator, forensic evidence is something that may be able to help him or her to assess a person's narrative. To a forensic scientist, forensic evidence is a trace that is to be analysed and evaluated (...) To a prosecutor, forensic evidence is something that will help him or her to convince the court of a defendant's culpability. And to a judge, forensic evidence is something reliable, an anchoring point in their assessment of a case. (Kruse, 2016, pp. 155-156)

Rather than serving as a machine for generating truth, DNA evidence relates to the expectations, epistemic cultures (Knorr-Cetina, 1999) and objectives of each social and professional group. There is no uniform and absolute perception of what DNA technologies can achieve in terms of criminal investigation: the expectations of a criminal investigator are distinct from the convictions of a scientist or from that which is expected from judges, lawyers, jurors or even from convicts. The presence of DNA technology also brings different traditions, cultures, languages and procedures into interaction: it immediately places into dialogue-and tensionscience and law (Edmond, 2001; Jasanoff, 2006). While science aims to convey "neutral" and "objective" knowledge, the intrinsic mission of the legal system is to try to establish the "truth of facts" based on scientific evidence and decide on the guilt or innocence of a person accused of committing a crime. In short, a DNA profile is subject to a transformative and contingent process that involves several actors, practices and organizational structures. To achieve the status as credible and robust, DNA evidence is subject to a series of events that highlight technical-scientific, legal and bureaucratic procedures, which sociologist Michael Lynch and his colleagues (Lynch et al., 2008) have termed "administrative objectivity". 


\section{The CSI Effect and the Associated Risks}

Criminal investigation using the potential of forensic genetics has attracted media attention, fuelling a phenomenon that many people call the "CSI effect". Television representations of criminal investigation focus on technology: the true heroes of police series are no longer detectives but instead forensic identification technologies (Kruse, 2010; Machado \& Prainsack, 2012). DNA evidence assumes a particularly important role in this regard since it symbolizes an ideology in which machines are more reliable and "safer" than human action and knowledge.

Although there is no consensus as to whether or not there is a "CSI effect", and the exact nature of this phenomenon (see Ley, Jankowski, \& Brewer, 2010), it is generally associated with the idea that judges and juries allegedly attribute more weight to evidence obtained through the application of molecular genetic techniques than to other types of evidence. Police stories inspired by DNA technology use cultural images that reflect a dominant idea, which is taken as being accurate and absolute, in relation to the work of researchers and the decisive power of forensic identification techniques - in particular, the perception that DNA evidence offers "infallible evidence". This set of ideas is propagated not only by television crime drama that focuses on the use of forensic science but also by journalists, lawyers and other actors in the justice system, such as judges, public prosecutors and eventually the police officers themselves.

Academic studies of how the media portray the uses of forensic investigation technologies in criminal investigations, and the effects that this coverage may have on different audiences, have increased in recent years. These studies focus especially in the adversarial judicial system, in which jurors and barristers take centre stage: juries (citizens) can decide whether or not the accused (defendants) are guilty, and it is up to the representatives of the parties involved to argue about the validity and meaning of the evidence admitted to trial. The judge often plays the role of a "passive arbitrator", responsible for defining the rules of the trial and whether or not the presented evidence may be admitted.

Existing literature on the alleged CSI effect has mainly discussed the way that television series shape audience perceptions of DNA technology, routine crime scene analysis procedures and the steps used to identify criminal offenders, given that audiences are generally distant from the "real world" of criminal investigation and court work. The main focus of these studies has been on the influence of series such as CSI on the 
respective viewers (Brewer \& Ley, 2010; Schweitzer \& Saks, 2007), on jurors-ordinary citizens summoned by courts to evaluate criminal cases that may be complex and may involve DNA evidence-and also on judges and police investigators themselves (Cole \& Dioso-Villa, 2007; Durnal, 2010; Huey, 2010; Shelton, Kim, \& Barak, 2006).

There is also a study group focusing on how a specific social group, individuals serving prison sentences, views media messages about DNA technology. According to existing studies (Machado \& Prainsack, 2012; Machado, Santos, \& Silva, 2011; Prainsack \& Kitzberger, 2009), prisoners tend to believe that DNA evidence has almost absolute power in terms of identification, based on the idea that the genetic profile is a technology with a probative and criminal identification capability which is far superior to fingerprints. However, the infallibility of DNA technology is not considered to be absolute by these inmates: they accentuate the possibility of human error and harbour strong suspicions of police officers or malicious individuals who may deliberately "plant" biological traces in crime scenes to incriminate them. They have also stated that they fear that the authorities will lie about the existence of DNA evidence to obtain confessions from criminal suspects (Machado et al., 2011).

Another aspect to be noted concerning the consequences that the TV series has on the professionals of the justice system is the concern harboured by the community of forensic scientists in relation to the alleged lack of public literacy. The CSI effect, together with a lack of literacy on the probabilistic framework involved in the interpretation of DNA evidence, is considered by many forensic geneticists to be the major obstacle in their task of communicating the results of DNA analysis to members of the criminal justice system (Amorim, 2012; Amorim et al., 2016). A recent study on the subject, based on the social representations of members of the forensic genetics community in Europe, highlights the scientists' concerns about how the professionals of the justice system and members of the public attribute an excessively "enthusiastic" and "optimistic" value in relation to DNA's capacity as evidence in court cases (Amelung, Granja, \& Machado, 2019). In response to these challenges, there are a few strategies for addressing such risk communication. Some examples include providing concrete models for good practice for evaluative expert reporting and suggesting standards for evaluative reporting within professional networks, such as the European Network of Forensic Science Institutes (ENFSI) (Biedermann, Champod, \& Willis, 2017). 


\section{CONCLUding Remarks}

The risk associated with the use of DNA technologies in the criminal justice system most commonly identified in the literature, in the fields of forensic genetics and the social sciences, regards the myth of the infallibility of genetic identification. Academic research reveals how notions related to the alleged infallibility of DNA technologies can condition the conduct of the police investigation itself, and how evidence is appraised in court. To this effect, it is desirable to question the framework of DNA evidence and consider the circumstances of each specific case. One possible way is to consider that the DNA profile should only be used as a means of backing up other types of evidence, and to safeguard the principle of equal access to evidence, defence and prosecution, as already occurs in most justice systems.

Another risk arising from the use of DNA technology, which should not be dissociated from the myth of its infallibility, concerns the risk of stigmatization arising from social inequalities, which are reproduced as soon as police forces decide to collect a biological sample of certain individuals to the detriment of others. The literature on sociology and criminology has systematically referred to the way that police practices primarily target individuals and communities who are considered to pose risks. This risk of suspicion is directed towards identification and subsequent collection of data (DNA profile and other biometric data) from the most deprived social groups and individuals belonging to so-called ethnic minorities (Chow-White \& Duster, 2011; Cole \& Lynch, 2006; Duster, 2006; Skinner, 2013; Williams \& Johnson, 2004b).

\section{REFERENCES}

Amelung, N., Granja, R., \& Machado, H. (2019). "We are victims of our own success": Challenges of communicating DNA evidence to "enthusiastic". In S. R. Davies \& U. Felt (Eds.), Exploring science communication: A science and technology studies approach. London: Sage.

Amorim, A. (2002). A Espécie das Origens. Genomas, Linhagens e Recombinações. Lisbon: Gradiva.

Amorim, A. (2012). Opening the DNA black box: Demythologizing forensic genetics. New Genetics and Society, 31(3), 259-270. https://doi.org/10.1080 /14636778.2012.687083

Amorim, A., Crespillo, M., Luque, J., Prieto, L., Garcia, O., Gusmão, L., ... Pinto, N. (2016). Formulation and communication of evaluative forensic 
science expert opinion-A GHEP-ISFG contribution to the establishment of standards. Forensic Science International: Genetics, 25, 210-213. https://doi. org/10.1016/j.fsigen.2016.09.003

Aronson, J. (2007). Genetic witness: Science, law, and controversy in the making of DNA profiling. Piscataway, NJ: Rutgers University Press.

Biedermann, A., Champod, C., \& Willis, S. (2017). Development of European standards for evaluative reporting in forensic science: The gap between intentions and perceptions. The International Journal of Evidence os Proof, 21(1-2), 14-29. https://doi.org/10.1177/1365712716674796

Bier, J. (2018). Bodily circulation and the measure of a life: Forensic identification and valuation after the Titanic disaster. Social Studies of Science, 48(5), 635662. https://doi.org/10.1177/0306312718801173

Brewer, P. R., \& Ley, B. L. (2010). Media use and public perceptions of DNA evidence. Science Communication, 32(1), 93-117. https://doi.org/10.1177/ 1075547009340343

Chow-White, P., \& Duster, T. (2011). Do health and forensic DNA databases increase racial disparities? PLoS Medicine, 8(10), el001100. https://doi. org/10.1371/journal.pmed.1001100

Cole, S. (2009). Forensics without uniqueness, conclusions without individualization: The new epistemology of forensic identification. Law, Probability and Risk, 8(3), 1-23. https://doi.org/10.1093/lpr/mgp016

Cole, S., \& Dioso-Villa, R. (2007). CSI and its effects: Media, juries, and the burden of proof. New England Law Review, 41(3), 435-470.

Cole, S., \& Lynch, M. (2006). The social and legal construction of suspects. Annual Review of Law and Social Science, 2, 39-60. https://doi.org/10.1146/ annurev.lawsocsci.2.081805.110001

Costa, S. (2017). Visibilities, invisibilities and twilight zones at the crime scene in Portugal. New Genetics and Society, 36(4), 375-399. https://doi.org/10.108 $0 / 14636778.2017 .1394835$

Durnal, E. (2010). Crime scene investigation (as seen on TV). Forensic Science International, 199(1-3), 1-5. https://doi.org/10.1016/j.forsciint.2010.02.015

Duster, T. (2003). Backdoor to engenics. New York: Routledge.

Duster, T. (2006). The molecular reinscription of race: Unanticipated issues in biotechnology and forensic science. Patterns of Prejudice, 40(4-5), 427-441. https://doi.org/10.1080/00313220601020148

Edmond, G. (2001). The law-set: The legal-scientific production of medical propriety. Science, Technology, \& Human Values, 26(2), 191-226. https://doi. org $/ 10.1177 / 016224390102600204$

Gill, P. (2014). Misleading DNA evidence: Reasons for miscarriages of justice. Amsterdam: Academic Press/Elsevier.

Gill, P. (2016). Analysis and implications of the miscarriages of justice of Amanda Knox and Raffaele Sollecito. Forensic Science International: Genetics, 23, 9-18. https://doi.org/10.1016/j.fsigen.2016.02.015 
Haimes, E. (2006). Social and ethical issues in the use of familial searching in forensic investigations: Insights from family and kinship studies. Journal of Law, Medicine of Ethics, 34(2), 263-276. https://doi.org/10.1111/ j.1748-720X.2006.00032.X

Hindmarsh, R., \& Prainsack, B. (Eds.). (2010). Genetic suspects: Global governance of forensic DNA profiling and databasing. Cambridge: Cambridge University Press.

Huey, L. (2010). "I've seen this on CSI": Criminal investigators' perceptions about the management of public expectations in the field. Crime, Media, Culture, 6(1), 49-68. https://doi.org/10.1177/1741659010363045

Jasanoff, S. (1995). Science at the bar. Law, science, and technology in America. Cambridge, MA and London, UK: Harvard University Press.

Jasanoff, S. (2006). Just evidence: The limits of science in the legal process. Journal of Law, Medicine \& Ethics, 34(2), 328-341. https://doi. org/10.1111/j.1748-720X.2006.00038.x

Kaye, D. H. (2009). Identification, individualization, uniqueness. Law, Probability and Risk, 8(2), 85-94.

Kim, J., Mammo, D., Siegel, M., \& Katsanis, S. (2011). Policy implications for familial searching. Investigative Genetics, 2(1), 1-22. https://doi. org/10.1186/2041-2223-2-22

Knorr-Cetina, K. (1999). Epistemic cultures. How the sciences make knowledge. Cambridge, MA; London, UK: Harvard University Press.

Kruse, C. (2010). Producing absolute truth: CSI science as wishful thinking. American Anthropologist, 112(1), 79-91. https://doi.org/10.1111/ j.1548-1433.2009.01198.x

Kruse, C. (2016). The social life of forensic evidence. Oakland, CA: University of California Press.

Lawless, C. (2016). Forensic science: A sociological introduction. Oxon and New York: Routledge.

Ley, B. L., Jankowski, N., \& Brewer, P. R. (2010). Investigating CSI: Portrayals of DNA testing on a forensic crime show and their potential effects. Public Understanding of Science, 21(1), 51-67. https://doi.org/10.1177/ 0963662510367571

Lynch, M. (2013). Science, truth, and forensic cultures: The exceptional legal status of DNA evidence. Studies in History and Philosophy of Biological and Biomedical Sciences, 44(1), 60-70. https://doi.org/10.1016/j.shpsc. 2012.09.008

Lynch, M., Cole, S., McNally, R., \& Jordan, K. (2008). Truth machine: The contentious history of DNA fingerprinting. Chicago: University of Chicago Press.

Lynch, M., \& Jasanoff, S. (1998). Contested identities: Science, law and forensic practice. Social Studies of Science, 28(5-6), 675-686. https://doi.org/10. $1177 / 030631298028005001$ 
Machado, H., \& Granja, R. (2019). Police epistemic culture and boundary work with judicial authorities and forensic scientists: The case of transnational DNA data exchange in the EU. New Genetics and Society, 38(3), 289-307. https:// doi.org/10.1080/14636778.2019.1609350

Machado, H., \& Prainsack, B. (2012). Tracing technologies: Prisoners' views in the era of CSI. Farnham, UK: Ashgate.

Machado, H., Santos, F., \& Silva, S. (2011). Prisoners' expectations of the national forensic DNA database: Surveillance and reconfiguration of individual rights. Forensic Science International, 210(1-3), 139-143. https://doi.org/10. 1016 /j.forsciint.2011.02.020

McCartney, C. (2006). Forensic identification and criminal justice: Forensic science, justice and risk. Cullompton: Willan Publishing.

Murphy, E. (2007). The new forensics: Criminal justice, false certainty, and the second generation of scientific evidence. California Law Review, 95(3), 721-797.

Nuffield Council on Bioethics. (2007). The forensic use of bioinformation: Ethical issues. London. Retrieved from https://nuffieldbioethics.org/assets/pdfs/ The-forensic-use-of-bioinformation-ethical-issues.pdf

Prainsack, B., \& Kitzberger, M. (2009). DNA behind bars: Other ways of knowing forensic DNA technologies. Social Studies of Science, 39(1), 51-79. https:// doi.org/10.1177/0306312708097289

Saks, M. J., \& Koehler, J. J. (2008). The individualization fallacy in forensic science evidence. Vanderbilt University Law Review, 61(1), 199-219. https:// papers.ssrn.com/sol3/papers.cfm?abstract_id=1432516

Santos, F. (2014). Making sense of the story: The dialogues between the police and forensic laboratories in the construction of DNA evidence. New Genetics and Society, 33(2), 181-203. https://doi.org/10.1080/14636778 .2014 .916186

Schiffer, B., \& Champod, C. (2008). Judicial error and forensic science: Pondering the contribution of DNA evidence. In C. R. Huff \& M. Killias (Eds.), Wrongful conviction. International perspectives on miscarriages of justice (pp. 33-55). Temple University Press.

Schweitzer, N. J., \& Saks, M. J. (2007). The CSI effect: Popular fiction about forensic science affects the public's expectations about real forensic science. Jurimetrics Journal, 47, 357-364.

Shelton, D. E., Kim, Y. S., \& Barak, G. (2006). A study of juror expectations and demands concerning scientific evidence: Does the "CSI Effect" exist? Vanderbilt Journal of Entertainment \& Technology Law, 9(2), 331-368.

Skinner, D. (2013). "The NDNAD has no ability in itself to be discriminatory": Ethnicity and the governance of the UK National DNA Database. Sociology, 47(5), 976-992. https://doi.org/10.1177/0038038513493539

Smith, L. A. (2017). The missing, the martyred and the disappeared: Global networks, technical intensification and the end of human rights genetics. Social 
Studies of Science, 47(3), 398-416. https://doi.org/10.1177/030631 2716678489

Toom, V. (2017). Finding closure, continuing bonds, and codentification after the 9/11 attacks. Medical Anthropology: Cross Cultural Studies in Health and Illness, 37(4), 267-279. https://doi.org/10.1080/01459740.2017.1337118 Toom, V. (2018). Cross-border exchange and comparison of forensic DNA data in the context of the Prïm Decision. Civil liberties, justice and home affairs. Retrieved from http://www.europarl.europa.eu/thinktank/en/document. html?reference=IPOL_STU(2018)604971

Williams, R., \& Johnson, P. (2004a). Circuits of surveillance. Surveillance \& Society, 2(1), 1-14. Retrieved from https://ojs.library.queensu.ca/index.php/ surveillance-and-society/article/view/3324/3286

Williams, R., \& Johnson, P. (2004b). "Wonderment and dread": Representations of DNA in ethical disputes about forensic DNA databases. New Genetics and Society, 23(2), 205-223. https://doi.org/10.1080/1463677042000237035

Williams, R., \& Johnson, P. (2008). Genetic policing: The use of DNA in criminal investigations. Cullompton: Willan Publishing.

Open Access This chapter is licensed under the terms of the Creative Commons Attribution 4.0 International License (http://creativecommons.org/licenses/ by $/ 4.0 /)$, which permits use, sharing, adaptation, distribution and reproduction in any medium or format, as long as you give appropriate credit to the original author(s) and the source, provide a link to the Creative Commons licence and indicate if changes were made.

The images or other third party material in this chapter are included in the chapter's Creative Commons licence, unless indicated otherwise in a credit line to the material. If material is not included in the chapter's Creative Commons licence and your intended use is not permitted by statutory regulation or exceeds the permitted use, you will need to obtain permission directly from the copyright holder.

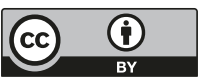

